International Journal of Current Micro6iology and Applied Sciences

ISSN: 2319-7706 Volume 9 Number 7 (2020)

Journal homepage: http://www.ijcmas.com

Review Article

https://doi.org/10.20546/ijcmas.2020.907.380

\title{
Microbial Biotransformation of Neonicotinoid Insecticides in Soil - A Review
}

\author{
Anup K. Bhattacherjee*, Pradeep K. Shukla and Abhay Dikshit \\ ICAR-Central Institute for Subtropical Horticulture, Rehmankhera, \\ Kakori, Lucknow - 226 101, UP, India \\ *Corresponding author
}

\section{A B S T R A C T}

\section{Keywords}

Neonicotinoid insecticides, Biodegradation, Bacteria, Soil environment

Article Info

Accepted: 22 June 2020 Available Online: 10 July 2020
Neonicotinoid insecticides are widely used nowadays to control many sucking insect-pests in several horticultural crops. They are neurotoxic and systemic in nature and their indiscriminate use may affect both target as well as beneficial insects. They are persistent insecticides and can enter food chain through soil application because of high water solubility. Microbes play an important role in removing toxic insecticides from soil environment and microbial degradation can be considered to be a cost effective mechanism to detoxify the insecticides. This article focuses on microbial biotransformation of neonicotinoid insecticides in soil environment. Many bacterial strains have been isolated from soil, which are capable of degrading neonicotinoids to non-toxic compounds by using these insecticides as additional carbon source. Microbes can fasten the transformation of insecticides in soil and thereby reducing the chance of their entry into food chain. Studies have indicated that enhanced biodegradation of neonicotinoids can be achieved with microbial consortium under favourable environmental conditions. However, substantial research on identification of neonicotinoids-degrading microbial strains and identification of the genes and enzymes responsible for their degradation need to be carried out to understand the transformation pathways and advance bioremediation efforts.

\section{Introduction}

During the last two decades neonicotinoid insecticides have become the most widely used, popular and fastest growing class of insecticides in modern agriculture including horticulture. They are broad spectrum systemic insecticides used to control many sucking and some chewing pests viz. aphids, thrips, jassids, mites, whiteflies, leaf miners, leaf hoppers, vine weevil, etc. With a global market share of $>25 \%$ and spread in 120 countries, neonicotinoids are proved to be the most important new class of synthetic insecticides. The name neonicotinoids are derived from nicotine and they are relatively new to market compared to other already established organochlorines, organophosphates, carbamates and synthetic pyrethroids insecticides. They act by binding 
strongly to nicotinic acetylcholine receptors (nACHR) in the central nervous system of insects causing over stimulation of their nerve cells, paralysis and death. Being highly water soluble and systemic in nature, they can migrate into all parts of treated plants. Neonicotinoids can be divided into three major groups:

Chloropyridinyl compounds (imidacloprid, nitenpyram, acetamiprid and thiacloprid)

Chlorothiazolyl compounds (thiamethoxam, clothianidine, imidaclothiz)

Tetrahydrofuryl compounds (dinotefuran)

Imidacloprid is the first neonicotinoid insecticide marketed by Bayer in 1992 and is the most widely used insecticide worldwide. Because of their specific mode of action and low resistance development among insects, neonicotinoids are continually used in agricultural and horticultural crops (Table 1). Due to this versatility in physicochemical properties, many types of agricultural applications including foliar spray, seed treatment, soil drench and stem injection are possible with them. Seed treatment with neonicotinoids is a proven and effective plant protection technique resulting not only in the increase in efficiency in protection but also in the reduction of labour cost. About $60 \%$ of these insecticides are applied as seed treatment especially for transgenic crops expressing Bacillus thuringiensis (Bt) toxin genes, as the treatment protects the plant seedlings before production of sufficient $\mathrm{Bt}$ toxin to provide effective pest resistance (Jeschke et al., 2011).

Imidacloprid, the first insecticide registered from this group, can be used as seed dressing, as soil treatment and foliar treatment in different crops like rice, cotton, cereals, maize, mango, sugar beet, vegetables, etc. to control sucking insects, soil insects, termites and some biting insects (Elbert et al., 1998). The IUPAC name for imidacloprid is [1-(6chloro-3-pyridinyl methyl)-N-nitro-2imidazolidinimine] and its chemical formula is $\mathrm{C}_{9} \mathrm{H}_{10} \mathrm{ClN}_{5} \mathrm{O}_{2}$. Acetamiprid is another insecticide from this group which was first registered during 1989 by Nippon Soda. Its chemical formula is $\mathrm{C}_{10} \mathrm{H}_{11} \mathrm{ClN}_{4}$ and IUPAC name is $\mathrm{N} \quad-[(6-$ chloro-3-pyridyl)methyl]-N'cyano-N-methyl acetamidine. This insecticide is used to control aphids, thrips, mirids, spider mites, whiteflies, European pine sawflies, leaf miners, leaf hoppers and vine weevil in leafy and fruiting vegetables, fruits like apple, citrus, pears, grapes, cotton, ornamental plants and flowers (Yao et al., 2006). Another compound from chloropyridinyl group is thiacloprid whose IUPAC name is [(2Z)-3 \{(6chloropyridin-3-yl) methyl \}-1,3-thiazolidin-2ylidene] cyanamide and chemical formula is $\mathrm{C}_{10} \mathrm{H}_{9} \mathrm{ClN}_{4} \mathrm{~S}$. It is effective against aphids, codling moth, leaf hoppers, leaf miners, psylla and whiteflies in potatoes, rapeseed, pome fruit, vegetables and ornamentals (Schuld and Schmuck, 2000). The fourth chloropyridinyl compound is nitenpyram which is a C-nitro compound consisting of 2-nitroethene-1,1diamine where one of the nitrogen bears ethyl and (6-chloro-3-pyridinyl) methyl moieties and the other nitrogen carries a methyl moiety. Its chemical formula is $\mathrm{C}_{11} \mathrm{H}_{15} \mathrm{ClN}_{4} \mathrm{O}_{2}$ and IUPAC name is (E)-N-(6-chloro-3pyridyl methyl)-N-ethyl-N'-methyl-2nitrovinylidenediamine. Nitenpyram is used mainly to kill fleas on dogs, puppies, cats and kittens (veterinary purpose) and less in agriculture (Plumb, 2015). Thiamethoxam is a second generation chlorothiazolylmethyl neonicotinoid insecticide discovered and registered by Syngenta Crop Protection in 1996. Its IUPAC name is 3-[(2-chloro-1, 3thiazol-5-yl)methyl]-5-methyl-N-nitro-1,3,5oxadiazinan-4-imine and chemical formula is $\mathrm{C}_{8} \mathrm{H}_{10} \mathrm{ClN}_{5} \mathrm{O}_{3} \mathrm{~S}$. Thiamethoxam can effectively be used to control hopper, seed 
weevil, scale insect and mealy bug in mango, other sucking soil and leaf-feeding pests like aphids, jassids, thrips and whitefly in vegetables, ornamentals, coffee, cotton, tropical plantations, rice and potatoes (Elbert et al., 2008). Like imidacloprid, it can also be used as foliar application, seed treatment and soil treatment. Clothianidin is another second generation neonicotinoid which is found effective against a wide variety of insects from Hemiptera, Thysanoptera, Diptera, Coleoptera and Lepidoptera families in various agricultural crops at small doses (Jeschke et al., 2011). The relatively less used and recently developed third chemical from second generation neonicotinoid is imidaclothiz whose chemical formula is $\mathrm{C}_{7} \mathrm{H}_{8} \mathrm{ClN}_{5} \mathrm{O}_{2} \mathrm{~S}$ and IUPAC name is (EZ)-1-(2chloro-1,3-thiazol-5-ylmethyl)- $N$ -

nitroimidazolidin-2-ylideneamine. It is found effective against sucking and chewing insect pests like aphids, plant hoppers, whitefly, leaf hoppers, beetles, etc. on various crops like vegetables including crucifers, tomatoes, citrus fruit, rice and tea (Liu et al., 2013). The last and third generation neonicotinoid commercialized by Mitsui Chemicals (Tokyo, Japan) in 1994 is dinotefuran. It is used for the control of aphids, whiteflies, thrips, leafhoppers, leafminers, sawflies, mole cricket, white grubs, lacebugs, billbugs, beetles, mealybugs, and cockroaches in/on leafy vegetables (except Brassica), in residential and commercial buildings, and for professional turf management (USEPA, 2004). It is also used in veterinary medicine. Its IUPAC name is 2-methyl-1-nitro-3[(tetrahydro-3-furanyl) methyl] guanidine and chemical formula is $\mathrm{C}_{7} \mathrm{H}_{14} \mathrm{~N}_{4} \mathrm{O}_{3}$.

\section{Persistence and fate of neonicotinoids in soil}

The persistence of neonicotinoid insecticides in soil depends mainly on environmental conditions and varies accordingly.
Temperature, $\mathrm{pH}$, moisture content, organic matter, soil structure and soil texture are some of the environmental factors affecting the degradation of these insecticides. Besides these, the nature of the insecticide, initial concentration and type of formulation used can also affect their persistence in soil. Among the neonicotinoid insecticides, imidacloprid and clothianidin are very highly persistent in soil with half-life ranging from 28-1250 and 148-6931 days, respectively; thiamethoxam and acetamiprid are moderate to highly persistent with half-life ranges from 7-353 and 31-450 days, respectively; thiacloprid and dinotefuran are less persistent with half-life of $<90$ days in soil (Goulson, 2013). In a laboratory study the half-life values of imidacloprid in three different types of soil (alluvial, laterite and coastal alkaline) were found between 34-45, 28-44 and 36-48 days, respectively, and it was found persistent up to 120 days in all three soils (Sarkar et al., 2001). A conversion of 75 per cent of the applied dose $(90 \mathrm{~g} / \mathrm{ha}$ ) of imidacloprid to four different metabolites in sugar beet field soil was reported by Rouchaud et al., (1994) where residual half-life was found to be 40 to 44 days without the application of any organic fertilizer. Imidacloprid and its matabolites become strongly bound to soil with the passage of time and thereby increasing the risk of their persistence (Cox et al., 1997; 1998). However, indirect application of imidacloprid (sprayed to mango trees) can lead to lower persistence in soil with a halflife of 17.5 days (Bhattacherjee et al., 2019). Soil organic matter content has an impact on the sorption of imidacloprid and its metabolites as evidenced by increasing sorption with increasing soil organic matter content which is significantly correlated (Liu et al., 2006). Thiamethoxam has low soil sorption and high leaching capability which makes it a potential contaminant of surface and underground water (Gupta et al., 2008). However, literature on bioavailability and 
sorption studies for other neonicotinoid insecticides is very sporadic.

\section{Environmental risks of neonicotinoids to non-target taxa}

Due to their high persistence and potential harmful effects on beneficial and not-target taxa, the use of neonicotinoid insecticides is currently generating concerns for the environment. Neonicotinoids are water soluble and possibility of leaching to soil water or ground water is always there though fishes are found less susceptible as compared to aquatic insects with $\mathrm{LC}_{50}$ values between 16 and 177 ppm depending on type of insecticides (Goulson, 2013). Being systemic in nature they are easily absorbed by plant root/leaves and translocated to other plant tissues via phloem/xylem without discriminating between harmful insects and beneficial insects (Krupke et al., 2012). Small amount of these insecticides can be found in pollen and nectar of seed-treated crops. They are also used to control many insect-pests in various fruit crops as foliar spray e.g. imidacloprid and thiamethoxam in mango, thiamethoxam in peach, thiacloprid in raspberries, etc. These fruit crops are pollinated either by cultured pollinators or by wild ones which can be affected by neonicotinoids. Pollinators can also be intoxicated when these insecticides are sprayed to vegetables and flowers in kitchen garden. Neonicotinoids can induce mortality to both honeybees and other pollinators like bumblebees, butterflies, dragonflies, wild bees, melipona bees, lacewings, lady bugs, bats, etc. (Krischik et al., 2007). However, supportive research data on bad/lethal effect of neonicotinoids on pollinators is not available. Cresswell (2011) has reported that imidacloprid at field-realistic dose under laboratory and semi-field conditions have very little lethal effect on honeybees. The recent data suggest that field-realistic exposure of bees to neonicotinoids present in nectar and pollen of seed-treated crops may not cause any substantial direct mortality (Marzaro et al., 2011; Tapparo et al., 2012). This type of research has not been conducted on other pollinating taxa like hoverflies and butterflies and mainly concentrates on the exposure of honeybees to seed-treated crops though there is a possibility of direct mortality if pollinators forage on crops which are treated with neonicotinoids mixed in irrigation water or as foliar spray. Important sublethal effects may occur to bees when exposed to sublethal doses of neonicotinoids which include reduced learning, less foraging ability and homing ability in both honeybees and bumblebees (Yang et al., 2008; Han et al., 2010; Mommaerts et al., 2010; Henry et al., 2012).

Many researches have been conducted to examine the toxicity of neonicotinoid insecticides to both target and non-target organisms viz. insects, birds, fishes, crustaceans, molluscs and mammals and insects are found as the most sensitive organisms, whether exposed via contact or ingestion. The most and least sensitive insects are brown plant hopper (Nilaparvata lugens) and Colorado potato beetle (Leptinotarsa decemlincata) whose weights and $\mathrm{LD}_{50}$ values are 1 and $130 \mathrm{mg}$ and 0.82 and $0.67 \mathrm{mg} / \mathrm{mg}$ body weight, respectively, indicating that variation in $\mathrm{LD}_{50}$ values depends of the weight of the particular insect (Goulson, 2013). Though the experiments over short period assess only mortality of insects, there are proof for important sublethal effects e.g. reduced feeding, less movement and reproduction, damaged immune system can be happened with much lower doses also as suggested by Alexander et al., (2007) in case of mayfly (Epeorus longimanus) where feeding was shortened for 4 days after exposure to water containing $0.1 \mathrm{ppb}$ of imidacloprid for $24 \mathrm{~h}$. Crustaceans, annelids 
and vertebrates are less susceptible than insects, though studies on toxicity of neonicotinoids to these groups of taxa are few. Goulson (2013) has reported that $\mathrm{LC}_{50}$ values for these insecticides ranged between $7.1 \mathrm{ppb}$ (over 28 days) in the amphipod Hyalella azteca to $361 \mathrm{ppm}$ (over $48 \mathrm{~h}$ exposure) in the brine shrimp Artemia sp. He has also reported that $\mathrm{LD}_{50}$ value in rats varies from $140 \mathrm{mg} / \mathrm{kg}$ body weight for acetamiprid to $5000 \mathrm{mg} / \mathrm{kg}$ body weight for clothianidin. Birds, especially insectivorous birds, are directly or indirectly affected by these insecticides with $\mathrm{LD}_{50}$ values ranging between $14 \mathrm{mg} / \mathrm{kg}$ body weight for imidacloprid in grey partridge and 1333 $\mathrm{mg} / \mathrm{kg}$ body weight in mallard ducks for clothianidin. For aquatic animals, fishes are comparatively less susceptible than aquatic insects with $\mathrm{LC}_{50}$ values varying from 16 to 177 ppm. When neonicotinoids are used as seed treatment, only 1.6 to 20 per cent of active ingredient is absorbed by the crop to protect it from target insect-pests, whilst the remainder pollutes the surrounding environment (Sur and Stork, 2003) damaging mainly soil microorganisms (Sabourmoghaddam et al., 2011) along with populations of earthworms, amphibians and aquatic insects (Kreutzweiser et al., 2008; van der Sluijs et al., 2014).

Though reviews discussing the environmental fate of neonicotinoids in details are available (Bonmatin et al., 2015), microbial biotransformation of neonicotinoids in soil is recently investigated topic of interest to reduce the persistence of these insecticides in soil. This chapter focuses on microbial biodegradation of neonicotinoid insecticides in soil either by single isolated bacterium or by a microbial consortium as microbial biodegradation may hold the key to successful bioremediation of the widespread neonicotinoids contamination of soil environment.

\section{Microbial degradation of neonicotinoid insecticides}

Microbial degradation of neonicotinoids mostly deals with the degradation by bacteriaeither by pure culture or by consortia. Microbial degradation of imidacloprid mainly revolves around the bacterial degradation of imidacloprid as it is the widely used neonicotinoid insecticide compared to other members of this group. Few researchers have studied the same for thiamethoxam, acetamiprid and thiacloprid. However, almost nothing has been done for clothianidin, nitenpyram and dinotefuran till date. Biodegradation of neonicotinoids by bacterial strains can be either catabolic, where the insecticide acts as a sole source of carbon/nitrogen for bacterial growth and development, or cometabolic, where biodegradation depends on both insecticide and supplementary or additional source of carbon or nitrogen. The factors affecting the bacterial degradation of a pesticide or a group of pesticides are chemical structure of pesticide and the catabolic activity of the degradation bacteria under some particular environmental conditions (Hussain et al., 2016).

\section{Imidacloprid}

Many bacterial strains were isolated and identified with imidacloprid degrading potential (Table 2). First report on isolation of imidacloprid degrading microorganism was probably published by Anhalt et al., (2007) where the authors isolated Leifsonia sp. strain PC-21 from agriculture soil and found that it was able to degrade imidacloprid in tryptic soy broth $37-58$ per cent at $27^{\circ} \mathrm{C}$ after 21 days of incubation. High performance liquid chromatography coupled with mass spectroscopy (LC-MS) analysis revealed the formation of 6 metabolites from degradation pathway among which two were identified as 
imidacloprid-guanidine and imidaclopridurea. The authors also reported that 6chloronicotinic acid was not detected during the experiment. They have also mentioned that degradation of imidacloprid by strain PC21 was a process of cometabolism which means imidacloprid can be metabolized without being used by the bacteria as a source of energy, carbon or nutrient. Pandey et al., (2009) have reported that Pseudomonas sp. $1 \mathrm{G}$ has the ability to transform imidacloprid and thiamethoxam to nitrosoguanidine and urea via aldehyde oxidase enzyme activity using glucose as supplementary carbon source. Dai et al., (2010) have observed that imidacloprid can be transformed to olefin metabolite via hydroxylation and dehydrogenation by the bacterial isolate Stenotrophomonas maltophilia CGMCC 1.178 with the help of glucose. An aerobic bacterium, isolated from agriculture field soil by enrichment culture and identified as Burkholderia cepacia strain $\mathrm{CH} 9$, was found capable of degrading imidacloprid (69\% of 50 $\mu \mathrm{g} / \mathrm{g}$ ) within 20 days of inoculation to a mineral-salts medium (Gopal et al., 2011). Shetti and Kaliwal (2012) have isolated Brevundimonas sp. MJ15 (SP-1) from cotton field soil with a history of imidacloprid exposure which can degrade imidacloprid through catabolic reaction in liquid minimal salt medium. Phugare et al., (2013) have studied cometabolic degradation of imidacloprid by Klebsiella pneumoniae $\mathrm{BCH}$ 1 and concluded that 6-chloronicotinic acid (6-CNA) was the final product of imidacloprid biotransformation via nitrosoguanidine and guanidine intermediates identified by gas chromatography-mass spectroscopy (GC-MS).

$\mathrm{Hu}$ et al., (2013) have isolated a gram negative rod shaped bacterium, Ochrobacterium sp. strain BCL-1, from tea rhizosphere soil which can catabolically degrade 67.67 per cent of $50 \mathrm{mg} / \mathrm{L}$ imidacloprid within 48 hours of application. The authors have also noticed that the biodegradation rate of imidacloprid by strain BCL-1 is significantly higher in tea soil compared to cabbage, potato and tomato soil. Ma et al., (2014) have noticed the formation of olefin and 5-hydroxy imidacloprid metabolites during cometabolic biotransformation of imidacloprid by a soil isolated bacteria Pseudoxanthomonas indica CGMCC 6648. Akoijam and Singh (2015) have noticed that dissipation of imidacloprid followed pseudo first-order kinetics after applying at 50, 100 and $150 \mathrm{mg} / \mathrm{kg}$ in sandy loam soil amended with Bacillus aerophilus with respective half-life values of 14.33, 15.05 and 18.81 days. Imidacloprid urea, olefin, 5-hydroxy imidacloprid, 6-CNA, nitrosimine and nitroguanidine were identified by HPLC as metabolites. A soil isolated bacterium Bacillus weihenstephanensis can catabolically degrade imidacloprid to 6-CNA in minimal salt medium and tryptic soy broth up to 46 and 78 per cent, respectively, in four weeks (Shetti et al., 2014). Among 50 bacterial isolates, collected from soils of vegetable forming areas, Rhizobium sp. showed the maximum imidacloprid degradation potential $(45.48 \%)$ and Bacillus sp. the minimum (25.36\%) (Sabourmoghaddam et al., 2015). Mycobacterium sp. strain MK6 was found capable of converting 99.7 per cent added imidacloprid $(150 \mu \mathrm{g} / \mathrm{mL})$ in less than 2 weeks $\left(t_{1 / 2}=1.6\right.$ days $)$ to 6 -CNA as its major metabolite and desnitro-olefin and desnitrodegradates as minor metabolites by using imidacloprid as sole nitrogen source (Kandil et al., 2015). Sharma et al., (2016) have reported that Bacillus aerophilus has maximum potential to degrade imidacloprid in clay loam soil under autoclaved condition with 93.45, 95.41 and 95.02 per cent degradation from 50, 100 and $150 \mathrm{mg} / \mathrm{kg}$ doses, respectively, compared to degradation under unautoclaved condition $(80.93,87.57$ 
and $85.95 \%$ from respective doses) after 56 days. Enterobacter sp. strain ATA1, isolated from paddy field soil at Punjab (India) with a history of 9-10 years of imidacloprid contamination, was found able to degrade imidacloprid as a co-metabolite in the presence of glucose in minimal salt medium. The degradation ranged between 30-40 per cent after $72 \mathrm{~h}$ of incubation resulting imidacloprid urea and imidacloprid guanidine as metabolites (Sharma et al., 2014). Ganvir and Sathe (2018) have observed that among 20 isolates from contaminated agricultural soil, Bacillus sp., Azotobacter sp., Azospirillum sp. and Pseudomonas sp. showed degradation potential of imidacloprid after 48-72 hours of incubation in minimal salt medium. Concentration of imidacloprid degraded by Azospirillum sp. was up to 500 $\mathrm{mg} / \mathrm{L}$, whereas for other three bacteria the concentration was up to $200 \mathrm{mg} / \mathrm{L}$. Imidacloprid can be degraded by Pseudomonas sp. up to 97 per cent in mango orchard soil after 28 days of application at 8 $\mathrm{mg} / \mathrm{kg}$ (Garg et al., 2018). Proposed degradation pathways of imidacloprid by various microorganisms are presented in Figure 1.

However, several metabolites produced during microbial biotransformation of imidacloprid in soil are more toxic and persistent than imidacloprid itself. Three widely reported metabolites are olefin, 4hydroxy imidacloprid and 5-hydroxy imidacloprid. Both 4-hydroxy and 5-hydroxy imidacloprid can easily be converted to olefin, which is 10 times more toxic to insects and mammals than imidacloprid (Nauen et al., 1999; Suchail et al., 2004).

\section{Acetamiprid}

The second neonicotinoid insecticide which was studied for microbial degradation is acetamiprid. Two microbes were identified for acetamiprid biotransformation in soil Stenotrophomonas sp. strain THZ-XP and Pigmentiphaga sp. strain AAP-1 (Tang et al., 2012; Wang et al., 2013b). The authors have reported that both the bacterial strains could transform acetamiprid into N-methyl-(6chloro-3-pyridyl) methylamine (ACE). In fact Pigmentiphaga sp. strain AAP-1 could utilize acetamiprid as a sole carbon, nitrogen and energy source, but with low growth rates (Wang et al., 2013b). Though ACE was identified as $\mathrm{N}$-deacetylation metabolism product by FT-IR, GC-MS and NMR analysis, but a full mineralization/degradation pathway was yet to be finalized. Cometabolism of acetamiprid by Rhodococcus sp. strain BCH 2 was studied in the presence of ammonium chloride and glucose as nitrogen and carbon sources, respectively (Phugare and Jadhav, 2015). Both ACE-VI and 6-CNA were detected as acetamiprid biodegradation products by GCMS analysis. Restriction of acetamiprid biodegradation by bacterial strain at high concentrations was also described by Wang et al., (2013a) using Ochrobactrum sp. D-12 which is capable of degrading acetamiprid at concentrations from 0 to $3000 \mathrm{mg} / \mathrm{L}$ within 48 $\mathrm{h}$ of incubation. The authors used Haldane inhibition model to fit the degradation rate at different concentrations and calculated maximum specific acetamiprid degradation rate (qmax) as 0.6394 for $6 \mathrm{~h}$, half-saturation constant (Ks) as $50.96 \mathrm{mg} / \mathrm{L}$ and the substrate inhibition constant (Ki) as $1879 \mathrm{mg} / \mathrm{L}$. Cometabolism of acetamiprid by Pseudoxanthomonas sp. strain AAP-7 in the presence of glucose as alternate carbon source was also studied where (E)-3-((()6chloropyridin-3-yl) methyl) methyl) amino) acrylonitrile and N-((6-chloropyridin-3-yl) methyl)-N-methylprop-1-en-2-amine were identified as hydrolytically demethylation product and both converting to ACE, reported as a dead-end product (Wang et al., 2013c). Biodegradation kinetics of acetamiprid for 
Pseudoxanthomonas sp. strain AAP-7 using concentrations ranging from 100 to $600 \mathrm{mg} / \mathrm{L}$ was also reported by the authors where degradation decreased with the increase in concentration after $60 \mathrm{~h}$ of incubation. Fusant$\mathrm{AC}$, an intergeneric fusion from Pigmentiphaga sp. strain AAP-1 and Pseudomonas sp. CTN-4 was constructed using protoplast-fusion technique and studied for degradation of acetamiprid and chlorothalonil (Wang et al., 2016). The fusant strain AC completely degraded 50-300 mg/L concentrations of acetamiprid within $5 \mathrm{~h}$ indicating a strong capability for acetamiprid degradation.

A substrate inhibition model was used to describe the degradation kinetics of acetamiprid by bacterium Stenotrophomonas maltophilia CGMCC 1.1788 where it was found transformed with a maximum specific degradation rate, half-saturation constant and inhibit constant of $1.775 / 36 \mathrm{~h}, 175.3 \mathrm{mg} / \mathrm{L}$ and $396.5 \mathrm{mg} / \mathrm{L}$, respectively, explaining that the rate of degradation of acetamiprid was restrained at high concentration (Chen et al., 2008). Dai et al., (2010) have reported that yeast Rhodotorula mucilaginosa strain IM-2 was able to degrade acetamiprid in sucrose mineral salt medium with half-lives of 3.7 days, while it did not degrade imidacloprid and imidaclothiz. Identification of metabolites indicated that the yeast selectively converted acetamiprid by hydrolysis to form an intermediate metabolite IM 1-3 (Figure 2). The yeast strain displayed biodegradability of acetamiprid in clay soils. In a partial cometabolic pathway for acetamiprid biodegradation by Pigmentiphaga sp. strain D-2 proposed by Yang et al., (2013), three metabolites namely N'-[(6-chloropyridin-3-yl) methyl]-N-methylacetamide, N'-cyano-Nmethyl-N-(pyridin-3-ylmethyl)

ethanimidamide and N-methyl (6-chloro-3pyridyl) methylamine were identified by LCMS analysis. The authors have also reported that a dechlorinated metabolite was detected for the first time in bacterial degradation of acetamiprid by LC-MS analysis and release of chloride ions during biodegradation. Zhou et al., (2014b) have mentioned that the nitrile hydratase enzyme of Ensifer meliloti CGMCC7333 is capable of degrading acetamiprid to an unstable metabolite $\mathrm{N}$ amidoamide which further degrades to chlorinated pyridyl methylmethanamine compound (Figure 3). Some others possible transformation pathways of acetamiprid by different microorganisms are presented in Figure 1.

\section{Thiacloprid}

Hydroxylation of thiacloprid to 4-hydroxy thiacloprid by bacterium Stenotrophomas maltophilia CGMCC1.1788 as a cometabolite with or without sucrose as a carbon and energy source has been reported in literature (Zhao et al., 2009). Tenfold increase in the efficiency of the bacterium was observed due to the presence of sucrose. Though 4-hydroxy thiacloprid does not convert to thiacloprid olefin under acidic condition, under alkaline condition it is oxidized and decyanated to form 4-ketone thiacloprid imine. Dai et al., (2010) have found that yeast Rhodotorula mucilaginosa strain IM-2 was able to degrade thiacloprid in sucrose mineral salt medium with half-lives of 14.8 days. Identification of metabolites indicated that the yeast selectively converted thiacloprid by hydrolysis of thiacloprid to form an amide derivative. The inoculated $R$. mucilaginosa IM-2 displayed biodegradability of thiacloprid in clay soils. The hydrolysis of the N-cyanoimino group to a N-carbamoylimino group containing metabolite (thiaclopride amide) is supposed to be the major degradation pathway of thiacloprid by a bacterium Variovorax boronicumulans strain J1 (Zhang et al., 2012). Expression of nitrile hydratase enzyme from $V$. boronicumulans by the resting cells of 
Escherichia coli can confirm the biodegradation of thiacloprid to thiacloprid amine by $V$. boronicumulans. Mediation of the major hydration pathway of thiacloprid biotransformation by nitrile hydratase enzyme activity was also proposed by the authors, similar to the biotransformation of acetamiprid by Ensifer meliloti CGMCC7333 as suggested by Zhou et al., (2014b). Nitrogen fixing bacterium E. meliloti CGMCC7333 is also capable of transforming thiacloprid into $\mathrm{N}$-carbamoylimine derivative presumably via the same nitrile hydratase enzyme activity (Ge et al., 2014). The biodegradation rate of thiacloprid varied from 0.11 to $2.89 \mu \mathrm{g} / \mathrm{mL} / \mathrm{h}$ with $E$. meliloti CGMCC7333, which hydrolysed thiacloprid to thiacloprid amide most rapidly. Therefore, it can be suggested that acetamiprid and thiacloprid share a common biodegradation pathway involving nitrile hydratase enzyme, which can provide an excellent opportunity to study microbial biotransformation pathway of neonicotinoid insecticides through expression of this enzyme in non-host bacteria. Proposed microbial biodegradation pathways of thiacloprid by numerous microorganisms are presented in Figure 4.

\section{Thiamethoxam}

Pandey et al., (2009) have mentioned that Pseudomonas sp. strain $1 \mathrm{G}$ is able to degrade thiamethoxam by producing the same 'magicnitro' $\left(=\mathrm{N}-\mathrm{NO}_{2}\right.$ ) group metabolites, the same way it transforms imidacloprid. The magicnitro group of thiamethoxam was converted to nitrosoguanidine, desnitroguanidine and urea metabolites by pure bacterial culture of Pseudomonas sp. strain 1G under microaerophilic growth conditions when supplemented with $10 \mathrm{mM}$ glucose. This study indicated that magic-nitro group of both imidacloprid and thiamethoxam might be transformed by bacterial enzymes in a nonspecific fashion. Another study by Zhou et al., (2013) on biotransformation of thiamethoxam by the nitrogen-fixing and plant growth promoting rhizobacterium Ensifer adhaerens strain TMX-23 has also suggested that the transformation of $\mathrm{N}$ nitroimino group $\left(=\mathrm{N}-\mathrm{NO}_{2}\right)$ to $\mathrm{N}-$ nitrosoimine or nitrosoguanidine $(=\mathrm{N}-\mathrm{NO})$ and urea $(=\mathrm{O})$ metabolites was the major metabolic pathway of thiamethoxam biogegradation. Biodegradation of thiamethoxam $(50 \mu \mathrm{g} / \mathrm{mL})$ in agricultural soil by Bacillus aeromonas strain IMBL 4.1 and Pseudomonas putida strain IMBL 5.2 was reported to be 45.28 and 38.23 per cent, respectively, in 15 days (Rana et al., 2015). Biodegradation of thiamethoxam in clay loam soil by Bacillus aerophilus strain IMBL4.1 has also been reported very recently with halflife values ranging from 11.15 to 12.54 days for 25,50 and $100 \mathrm{mg} / \mathrm{kg}$ doses (Rana and Gupta, 2019). Microbial biotransformation pathways of thiacloprid by different microbes are presented in Figure 4.

\section{Biodegradation of neonicotinoids by microbial consortium}

Now-a-days researchers are exploring the idea of using microbial consortia and unculturable microbes for biodegradation of neonicotinoid insecticides in soil. Results showed that microbial consortia along with unidentified microbes might play a significant role in rapid in situ biodegradation of insecticides in soil. Microbial degradation of four neonicotinoid insecticides imidacloprid, acetamiprid, thiacloprid and imidaclothiz in soil was studied by Liu et al., (2011). Much faster degradation for acetamiprid and thiacloprid (94.0 and 98.8\%, respectively) was observed within 15 days compared to imidacloprid $(22.5 \%)$ and imidaclothiz $(25.1 \%)$ in unsterilized soils after 25 days. In sterile soils, the degradation rates were much slower for these insecticides $(21.4,27.6,9.0$ and $0 \%$ for acetamiprid, thiacloprid, imidaclothiz and 
imidacloprid, respectively). The degradation products identified were olefin, nitrosoguanidine metabolites for imidacloprid and imidaclothiz and an amide metabolite for thiacloprid). A consortium of four bacteria Bacillus subtilis GB03, Bacillus subtilis FZB24, Bacillus amyloliquefaciens IN937a and Bacillus pumilus SE34 was reported capable of degrading 11-22 per cent of thiamethoxam in liquid culture medium (Myresiotis et al., 2012). Sharma et al., (2014) have reported that biodegradation of imidacloprid by a consortium of Bacillus aerophilus and Bacillus alkalinitrilicus led to the formation of 6-CNA and imidacloprid nitrosoguanidine as metabolites where 50, 100 and $150 \mathrm{mg} / \mathrm{kg}$ doses of imidacloprid can be degraded in clay loam soil under autoclaved condition with half-life ranging from 14-16 days after 56 days of treatment.

Degradation of imidacloprid in soil was 69 per cent by a consortium of three bacteria isolated from agricultural field soil of Uttarakhand, India after 20 days as compared to only 15 per cent degradation in control soil (Negi et al., 2014). However, imidacloprid degradation in soil slurry was 3.6 times higher in consortium than in control (76 and $21 \%$, respectively). Shaikh et al., (2014) have reported that a consortium of four Bacillus sp. showed maximum degradation of imidacloprid between 48-72 hours after incubation and 6-CNA was the degradation product identified by HPLC. Though most of the imidacloprid biodegradation pathways conclude that 6-CNA is the final metabolite, a 6-CNA mineralizing chemolithoautotrophic bacterium Bradyrhizobiaceae strain SG-6C has also been mentioned (Pearce et al., 2011; Shettigar et al., 2012) which indicates that a pathway of complete mineralization of imidacloprid is possible. Soil microbial degradation of imidacloprid and thiamethoxam in unsterllized soil resulted three degradation products (olefin, olefin desnitro and urea) for imidacloprid and two degradation products (clothianidin and clothianidin TZMU) for thiamethoxam compared to minimal detection of these metabolites in sterilized soil (Vineyard and Stewart, 2017). Comomonadaceae sp., the uncultivable beta proteobacteria, was found capable of biodegradation of thiamethoxam in soil (Zhou et al., 2014a).

These studies indicate that microbial consortia can be used successfully to detoxify neonicotinoid insecticides in contaminated soil. However, the complexity of culturing/harnessing such type of microbial consortia makes them difficult to apply for bioremediation of neonicotinoid insecticides in soil environment without detailed knowledge of bacteria, other microbes and enzymatic processes involved.

\section{Optimum conditions for biodegradation of neonicotinoids}

Biodegradation of pesticides by bacterial isolates can be affected by environmental factors like biotic and abiotic parameters. These parameters include soil texture, soil $\mathrm{pH}$, temperature, aeration, status of soil nutrients, chemical structure of pesticides and their bioavailability along with inoculum size of microbial community and their catabolic activity. For successful bioremediation of a pesticide in a particular soil environment with accelerated microbial activity, the optimization of environmental conditions is highly necessary. Desired results may not be sometimes obtained for bioremediation of pesticides in soil due to poor application and improper handling of biotic and abiotic factors required for the growth and activity of degrading microbes. The optimum conditions for biodegradation of neonicotinoid insecticides by different microorganisms are provided in Table 2. 
Table.1 Dosages of neonicotinoid pesticides in different crops used against various insect-pests and their waiting periods in the soil. (Source: http://agritech.tnau.ac.in/crop protection/pdf/5 major use insecticides.pdf)

\begin{tabular}{|c|c|c|c|c|}
\hline $\begin{array}{l}\text { Name of } \\
\text { pesticide }\end{array}$ & $\begin{array}{l}\text { Crop } \\
\text { (Dosage g a.i./ha) }\end{array}$ & $\begin{array}{l}\text { Waiting } \\
\text { Period } \\
\text { (days) }\end{array}$ & Insect-pests & Chemical structure \\
\hline Imidacloprid & $\begin{array}{l}\text { Chilly (25-50) } \\
\text { Tomato (30-35) } \\
\text { Okra (20) } \\
\text { Mango (0.4-0.8 } \\
\text { g/tree) } \\
\text { Citrus (10) } \\
\text { Grapes (0.06-0.08) } \\
\text { Sunflower (20) } \\
\text { Groundnut (20-25) } \\
\text { Sugarcane (70) } \\
\text { Cotton (20-25) } \\
\text { Paddy (20-25) }\end{array}$ & $\begin{array}{c}40 \\
3 \\
3 \\
45 \\
\\
15 \\
32 \\
30 \\
40 \\
45 \\
40 \\
40\end{array}$ & $\begin{array}{l}\text { Aphid } \\
\text { Whitefly } \\
\text { Jassid, Thrips } \\
\text { Brown plant } \\
\text { hopper } \\
\text { Whitebacked } \\
\text { plant- hopper } \\
\text { Green leaf } \\
\text { hopper } \\
\text { Termite } \\
\text { Hopper } \\
\text { Leaf miner } \\
\text { Psylla } \\
\text { Flea bettle }\end{array}$ & \\
\hline Acetamiprid & $\begin{array}{l}\text { Okra (15) } \\
\text { Cabbage (15) } \\
\text { Chilli (10-20) } \\
\text { Cotton (10-20) } \\
\text { Rice (10-20) }\end{array}$ & $\begin{array}{c}3 \\
7 \\
3 \\
15 \\
7\end{array}$ & $\begin{array}{l}\text { Aphids } \\
\text { Jassids } \\
\text { White flies } \\
\text { Thrips } \\
\text { Brown plant } \\
\text { hopper }\end{array}$ & $\mathrm{H}_{3}$ \\
\hline Thiamethoxam & $\begin{array}{l}\text { Tomato (50) } \\
\text { Brinjal (50) } \\
\text { Potato foliar } \\
\text { application (25) } \\
\text { Okra (25) } \\
\text { Cotton (25) } \\
\text { Mustard (12.5-25.0) }\end{array}$ & $\begin{array}{c}5 \\
3 \\
75 \\
\\
5 \\
21 \\
21\end{array}$ & $\begin{array}{l}\text { Stem borer } \\
\text { Gall midge } \\
\text { Leaf folder } \\
\text { BPH } \\
\text { WBPH } \\
\text { GLH } \\
\text { Thrips }\end{array}$ & \\
\hline
\end{tabular}




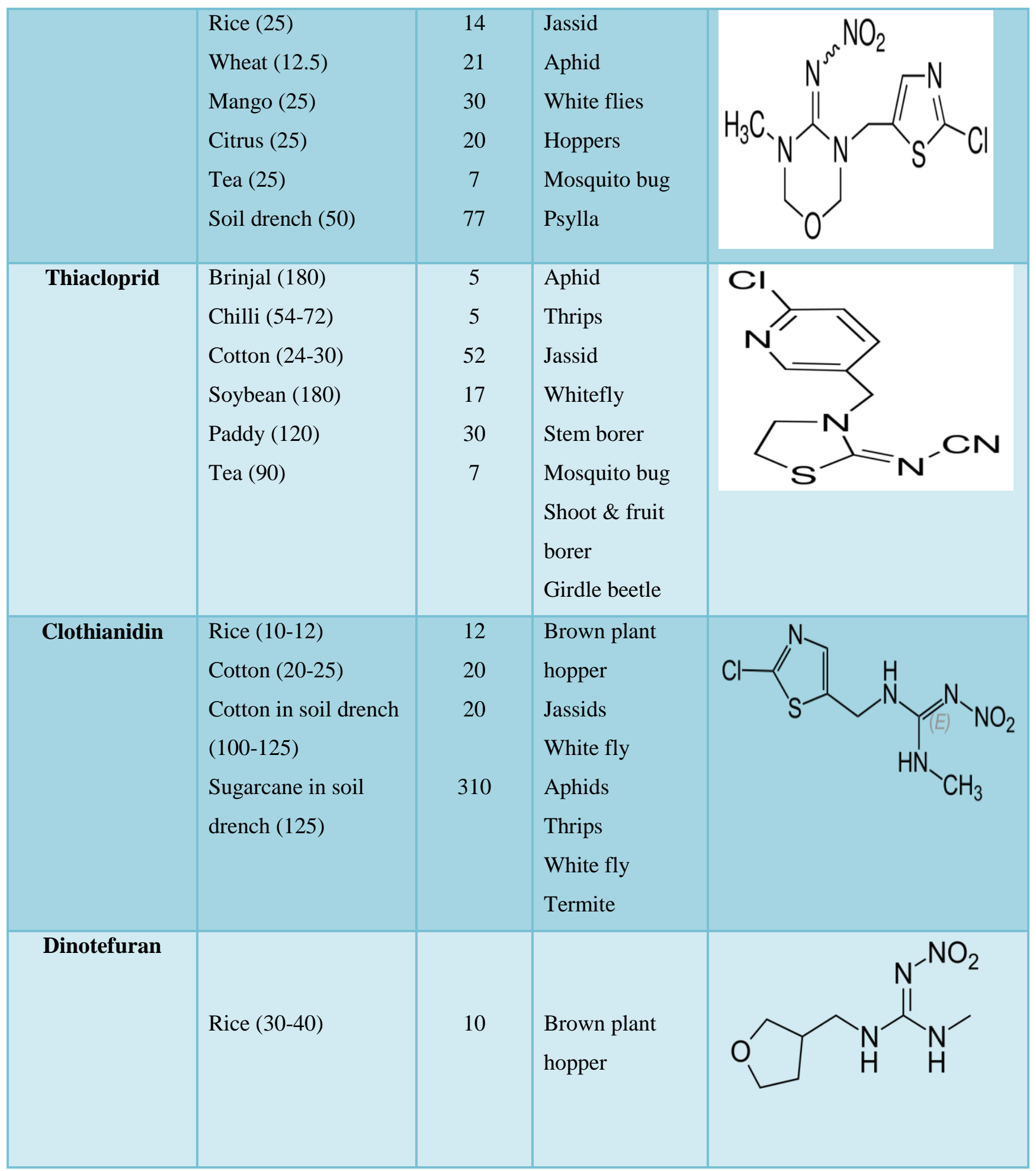


Table.2 Microbial strains capable of degrading neonicotinoid insecticides with optimum biodegradation conditions

\begin{tabular}{|c|c|c|c|c|}
\hline Microorganism & Source & $\begin{array}{l}\text { Mode of } \\
\text { degradation }\end{array}$ & $\begin{array}{l}\text { Optimal } \\
\text { biodegradation } \\
\text { conditions }\end{array}$ & Reference \\
\hline \multicolumn{5}{|l|}{ Imidacloprid } \\
\hline $\begin{array}{l}\text { Bacillus } \\
\text { alkalinitrilicus and } \\
\text { Bacillus aerophilus }\end{array}$ & Sugarcane field soils & $\begin{array}{l}\text { Cometabolic, } \\
\text { mixed culture }\end{array}$ & Soil slurry & $\begin{array}{l}\text { Akoijam and Singh } \\
\text { (2015) } \\
\text { Sharma et al. (2014) }\end{array}$ \\
\hline Bacillus sp. & Rhizospheric soil & Catabolic $(\mathrm{C}, \mathrm{N})$ & $30-35^{\circ} \mathrm{C}, \mathrm{pH} 7$ & Shaikh et al. (2014) \\
\hline Brevundimonas sp. & Cotton field soils & Catabolic $(\mathrm{C}, \mathrm{N})$ & $37^{\circ} \mathrm{C}, 120 \mathrm{ppm}$ & $\begin{array}{l}\text { Shetti and Kaliwal } \\
\text { (2012) }\end{array}$ \\
\hline $\begin{array}{l}\text { Bacillus } \\
\text { weihenstephanensis }\end{array}$ & Soil & Catabolic $(\mathrm{C}, \mathrm{N})$ & $\begin{array}{l}\text { Liquid minimal } \\
\text { Medium, } 22^{\circ} \mathrm{C}, \mathrm{pH} \\
7.0\end{array}$ & Shetti et al. (2014) \\
\hline Burkholderia cepacia & Agriculture field soil & Catabolic & $\begin{array}{l}\text { Liquid tryptic soy } \\
\text { broth, spiked } \\
\text { imidacloprid } \\
(50 \mu \mathrm{g} / \mathrm{mL})\end{array}$ & Gopal et al. (2011) \\
\hline $\begin{array}{l}\text { Klebsiella } \\
\text { pneumoniae } \\
\text { BCH-1 }\end{array}$ & $\begin{array}{l}\text { Pesticide- } \\
\text { contaminated } \\
\text { agricultural soil }\end{array}$ & Cometabolic & $\mathrm{pH} 7,30^{\circ} \mathrm{C}$, static & Phugare et al. (2013) \\
\hline Leifsonia sp. PC-21 & Agricultural soil & $\begin{array}{l}\text { Cometabolic } \\
\text { (glucose, } \\
\text { succinate) }\end{array}$ & - & Anhalt et al. (2007) \\
\hline $\begin{array}{l}\text { Mycobacterium sp. } \\
\text { strain MK6 }\end{array}$ & Agricultural soil & Catabolic (N) & $\begin{array}{l}\text { Liquid minimal } \\
\text { medium }\end{array}$ & Kandil et al. (2015) \\
\hline Ochrobactrum sp. & Tea rhizosphere soil & Catabolic (C) & $30^{\circ} \mathrm{C}, \mathrm{pH} 8$ & Hu et al. (2013) \\
\hline Pseudomonas sp. 1G & $\begin{array}{l}\text { Neonicotinoid- } \\
\text { exposed golf course } \\
\text { soil }\end{array}$ & $\begin{array}{l}\text { Cometabolic } \\
\text { (glucose) }\end{array}$ & $\begin{array}{l}28^{\circ} \mathrm{C}, \\
\text { microaerophilic }\end{array}$ & Pandey et al. (2009) \\
\hline $\begin{array}{l}\text { Pseudoxanthomonas } \\
\text { indica }\end{array}$ & Rhizospheric soils & $\begin{array}{l}\text { Cometabolic } \\
\text { (glucose) }\end{array}$ & $\begin{array}{l}\text { Liquid minimal } \\
\text { medium }\end{array}$ & Ma et al.(2014) \\
\hline Rhizobium sp. & $\begin{array}{l}\text { Vegetable farming } \\
\text { areas }\end{array}$ & Catabolic (C) & $\begin{array}{l}\text { Liquid minimal } \\
\text { medium }\end{array}$ & $\begin{array}{l}\text { Sabourmoghaddam et } \\
\text { al. (2014) }\end{array}$ \\
\hline \multicolumn{5}{|l|}{ Acetamiprid } \\
\hline $\begin{array}{l}\text { Ensifer meliloti } \\
\text { CGMCC } 7333\end{array}$ & Rhizosphere soils & $\begin{array}{l}\text { Catabolic }(\mathrm{N}) \\
\text { N-Aminoamide } \\
\text { IM-1-2 }\end{array}$ & $30{ }^{\circ} \mathrm{C}$, resting cells & Zhou et al. (2014b) \\
\hline Fusarium sp. CS-3 & $\begin{array}{l}\text { Acetamiprid- } \\
\text { contaminated soil }\end{array}$ & $\begin{array}{l}\text { Acetamiprid as } \\
\text { sole carbon } \\
\text { source }\end{array}$ & $\begin{array}{l}20-42^{\circ} \mathrm{C}, \mathrm{pH} 5.0- \\
8.0\end{array}$ & Shi et al. (2018) \\
\hline $\begin{array}{l}\text { Ochrobactrum sp. } \\
\text { D-12 }\end{array}$ & $\begin{array}{l}\text { Polluted agricultural } \\
\text { soil }\end{array}$ & Catabolic & $\begin{array}{l}25-35^{\circ} \mathrm{C} \\
\mathrm{pH} 6-8\end{array}$ & Wang et al. (2013a) \\
\hline Pigmentiphaga sp. & Pesticide- & Catabolic & $30^{\circ} \mathrm{C}$, resting cells, & Wang et al. (2013b) \\
\hline
\end{tabular}




\begin{tabular}{|c|c|c|c|c|}
\hline AAP-1 & $\begin{array}{l}\text { contaminated } \\
\text { factory soil }\end{array}$ & & $\mathrm{pH} 7$ & \\
\hline $\begin{array}{l}\text { Pigmentiphaga sp. } \\
\text { D-2 }\end{array}$ & $\begin{array}{l}\text { Wastewater from } \\
\text { acetamiprid- } \\
\text { manufacturing } \\
\text { factory }\end{array}$ & Catabolic (C) & $\begin{array}{l}30-45^{\circ} \mathrm{C} \\
\mathrm{pH} 5-10\end{array}$ & Yang et al. (2013) \\
\hline $\begin{array}{l}\text { Pseudomonas sp. } \\
\text { FH2 }\end{array}$ & $\begin{array}{l}\text { Sludge from } \\
\text { pesticide factory }\end{array}$ & Cometabolic & $30^{\circ} \mathrm{C}, \mathrm{pH} 7$ & Yao and Min (2006) \\
\hline $\begin{array}{l}\text { Pseudoxanthomonas } \\
\text { sp. AAP-7 }\end{array}$ & $\begin{array}{l}\text { Pesticide- } \\
\text { contaminated } \\
\text { factory soil }\end{array}$ & Cometabolic & $\begin{array}{l}30{ }^{\circ} \mathrm{C} \text {, resting cells, } \\
\mathrm{pH} 7\end{array}$ & Wang et al. (2013c) \\
\hline $\begin{array}{l}\text { Rhodococcus sp. } \\
\text { BCH-2 }\end{array}$ & $\begin{array}{l}\text { Pesticide- } \\
\text { contaminated soil }\end{array}$ & $\begin{array}{l}\text { Cometabolic (6- } \\
\text { CNA) }\end{array}$ & $35^{\circ} \mathrm{C}, \mathrm{pH} 7$, static & $\begin{array}{l}\text { Phugare and Jadhav } \\
\text { (2015) }\end{array}$ \\
\hline $\begin{array}{l}\text { Rhodotorula } \\
\text { mucilaginosa IM-2 }\end{array}$ & Clay soil & Catabolic (C) & $\begin{array}{l}\text { Mineral salt } \\
\text { medium }\end{array}$ & Dai et al. (2010) \\
\hline $\begin{array}{l}\text { Stenotrophomonas sp. } \\
\text { THZ-XP }\end{array}$ & $\begin{array}{l}\text { Sludge from an } \\
\text { acetamiprid- } \\
\text { producing factory }\end{array}$ & $\begin{array}{l}\text { Cometabolic } \\
\text { ACE-3 }\end{array}$ & $30^{\circ} \mathrm{C}, \mathrm{pH} 7$ & Tang et al. (2012) \\
\hline $\begin{array}{l}\text { Stentrophomonas } \\
\text { maltophila } \\
\text { CGMCC } 1.178\end{array}$ & Purchased & Cometabolic & $30^{\circ} \mathrm{C}, \mathrm{pH} 7.2$ & Chen et al. (2008) \\
\hline \multicolumn{5}{|l|}{ Thiacloprid } \\
\hline $\begin{array}{l}\text { Ensifer meliloti } \\
\text { CGMCC7333 }\end{array}$ & Rhizosphere soils & Catabolic (N) & $30^{\circ} \mathrm{C}$ & Ge et al. (2014) \\
\hline $\begin{array}{l}\text { Rhodotorula } \\
\text { mucilaginosa IM-2 }\end{array}$ & Clay soil & Catabolic (C) & $\begin{array}{l}\text { Mineral salt } \\
\text { medium }\end{array}$ & Dai et al. (2010) \\
\hline $\begin{array}{l}\text { Stenotrophomonas } \\
\text { maltophilia CGMCC } \\
1.178\end{array}$ & Purchased & Cometabolic & $\begin{array}{l}30{ }^{\circ} \mathrm{C}, \mathrm{pH} 7.2 \\
\text { (resting cells) }\end{array}$ & Zhao et al. (2009) \\
\hline $\begin{array}{l}\text { Variovorax } \\
\text { boronicumulans J1 }\end{array}$ & Agricultural soil & $\begin{array}{l}\text { Cometabolic } \\
\text { (resting cells) }\end{array}$ & $30^{\circ} \mathrm{C}, \mathrm{pH} 7.2$ & Zhang et al. (2012) \\
\hline \multicolumn{5}{|l|}{ Thiamethoxam } \\
\hline $\begin{array}{l}\text { Bacillus aeromonas } \\
\text { IMBL } 4.1 \text { and } \\
\text { Pseudomonas putida } \\
\text { IMBL 5.2 }\end{array}$ & Agricultural soil & Cometabolic & $\begin{array}{l}37^{\circ} \mathrm{C}, \mathrm{pH} 6.0-6.5 \text {, } \\
\text { mineral salt } \\
\text { medium }\end{array}$ & Rana et al. (2015) \\
\hline $\begin{array}{l}\text { Bacillus aerophilus } \\
\text { IMBL4.1 }\end{array}$ & Clay loam soil & Cometabolic & - & $\begin{array}{l}\text { Rana and Gupta } \\
\text { (2019) }\end{array}$ \\
\hline $\begin{array}{l}\text { Ensifer adhaerens } \\
\text { TMX-23 }\end{array}$ & $\begin{array}{l}\text { Rhizosphere soil } \\
\text { around soybean } \\
\text { plant }\end{array}$ & Catabolic $(\mathrm{C}, \mathrm{N})$ & $30^{\circ} \mathrm{C}$ & Zhou et al. (2013) \\
\hline Pseudomonas sp.1G & $\begin{array}{l}\text { Neonicotinoid- } \\
\text { exposed golf course } \\
\text { soil }\end{array}$ & Cometabolic & $\begin{array}{l}28^{\circ} \mathrm{C}, \\
\text { microaerophilic }\end{array}$ & Pandey et al. (2009) \\
\hline
\end{tabular}


Fig.1 Proposed degradation pathways of imidacloprid and acetamiprid by different microbes. (Source: Hussain et al., 2016, FEMS Microbiology Letters)

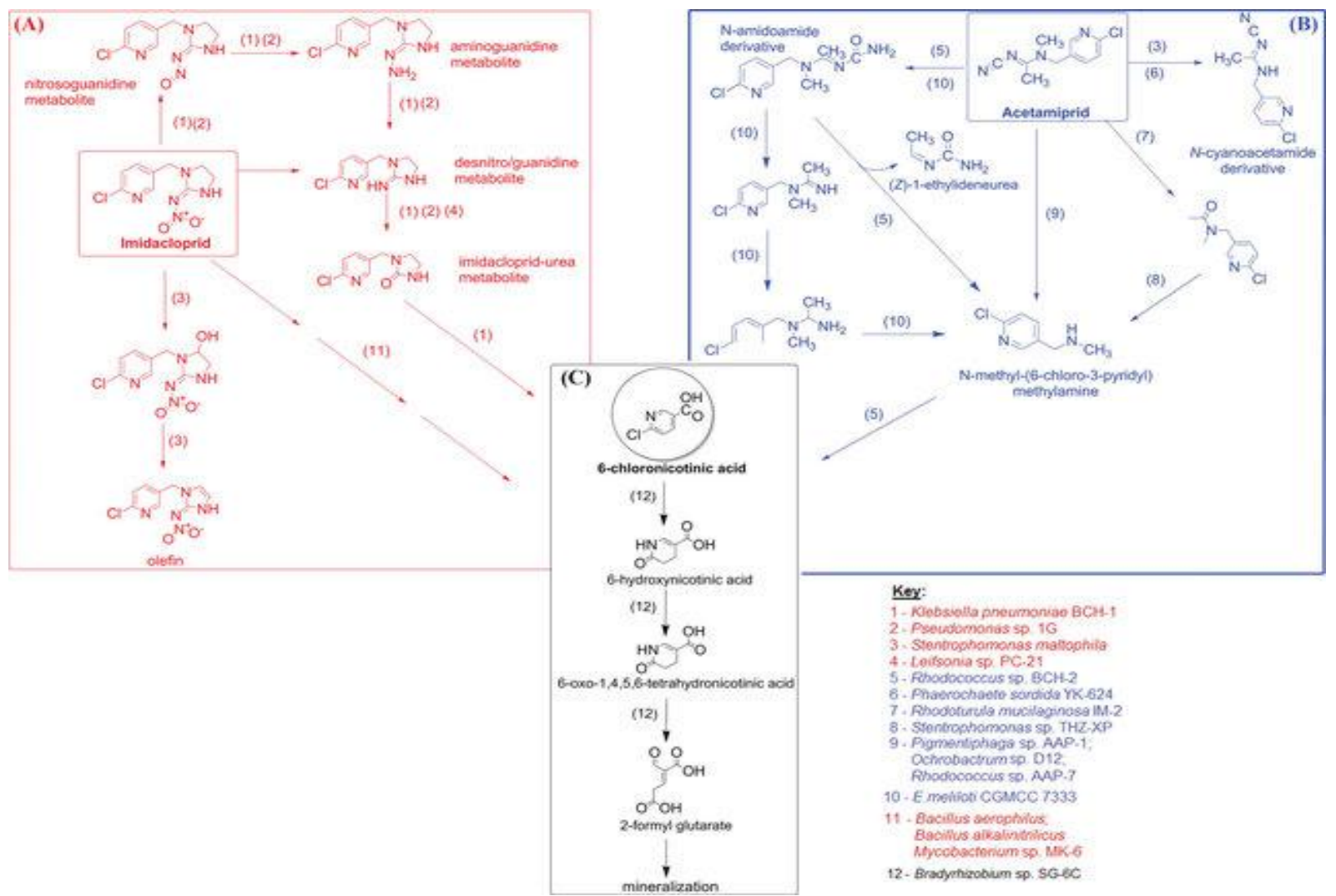

Fig.2 Proposed degradation pathways of acetamiprid and thiacloprid by yeast strain in sucrose mineral salt medium. (Source: Dai et al., 2010, J Agric Food Chem)
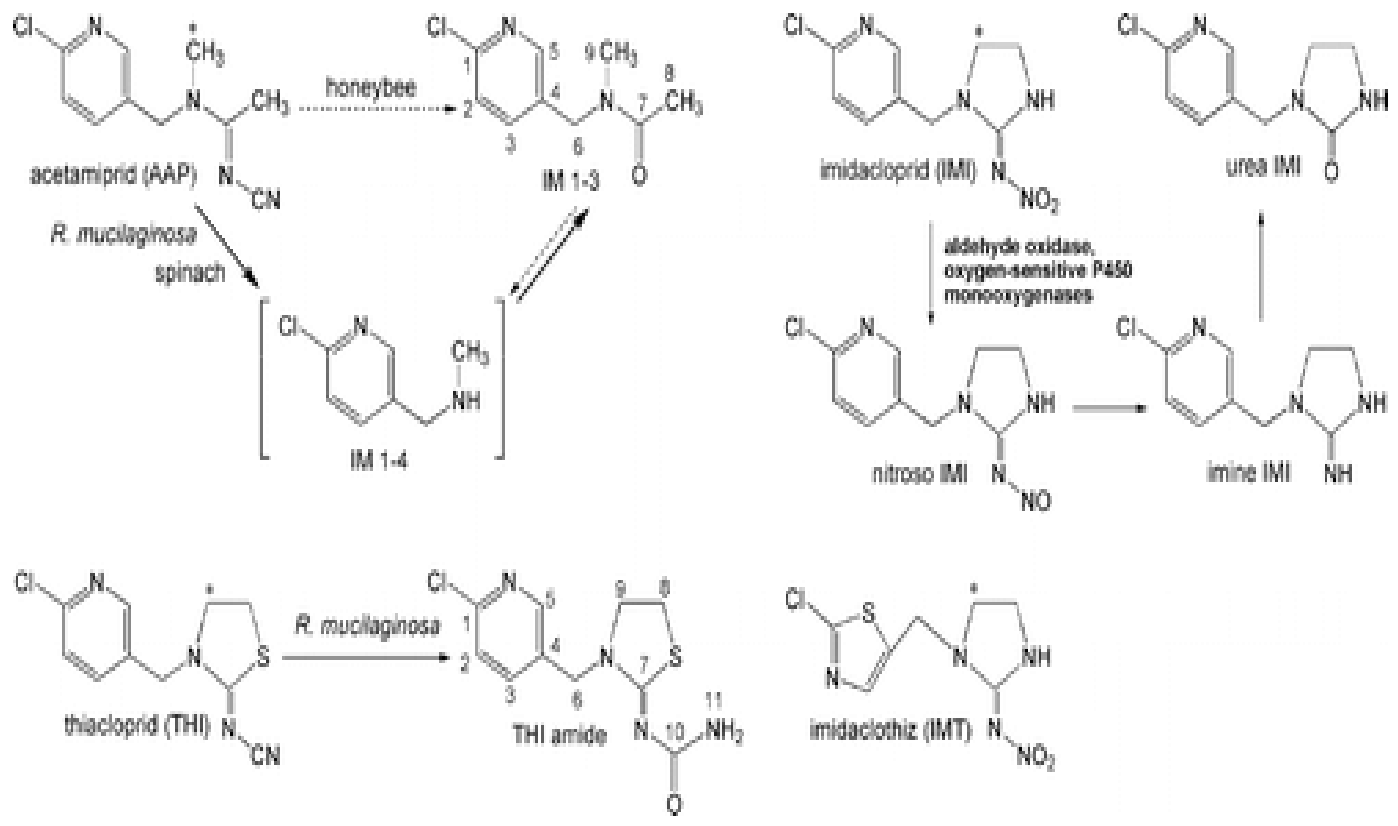
Fig.3 Possible degradation products of acetamiprid by nitrogen-fixing bacteria Ensifer meliloti CGMCC7333 (Source: Zhou et al., 2014b, J Agric Food Chem)

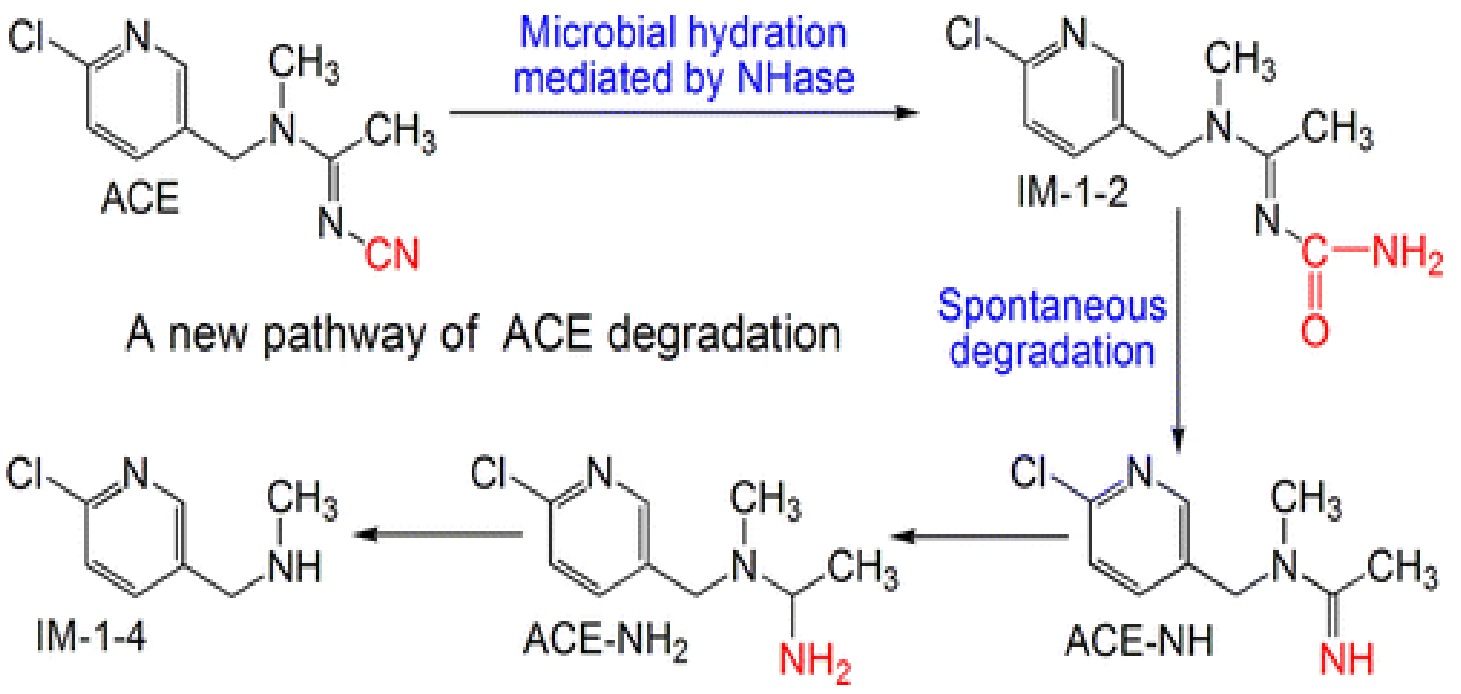

Fig.4 Microbial degradation pathways of thiacloprid (A) and thiamethoxam (B) in soil (Source: Hussain et al., 2016, FEMS Microbiology Letters)
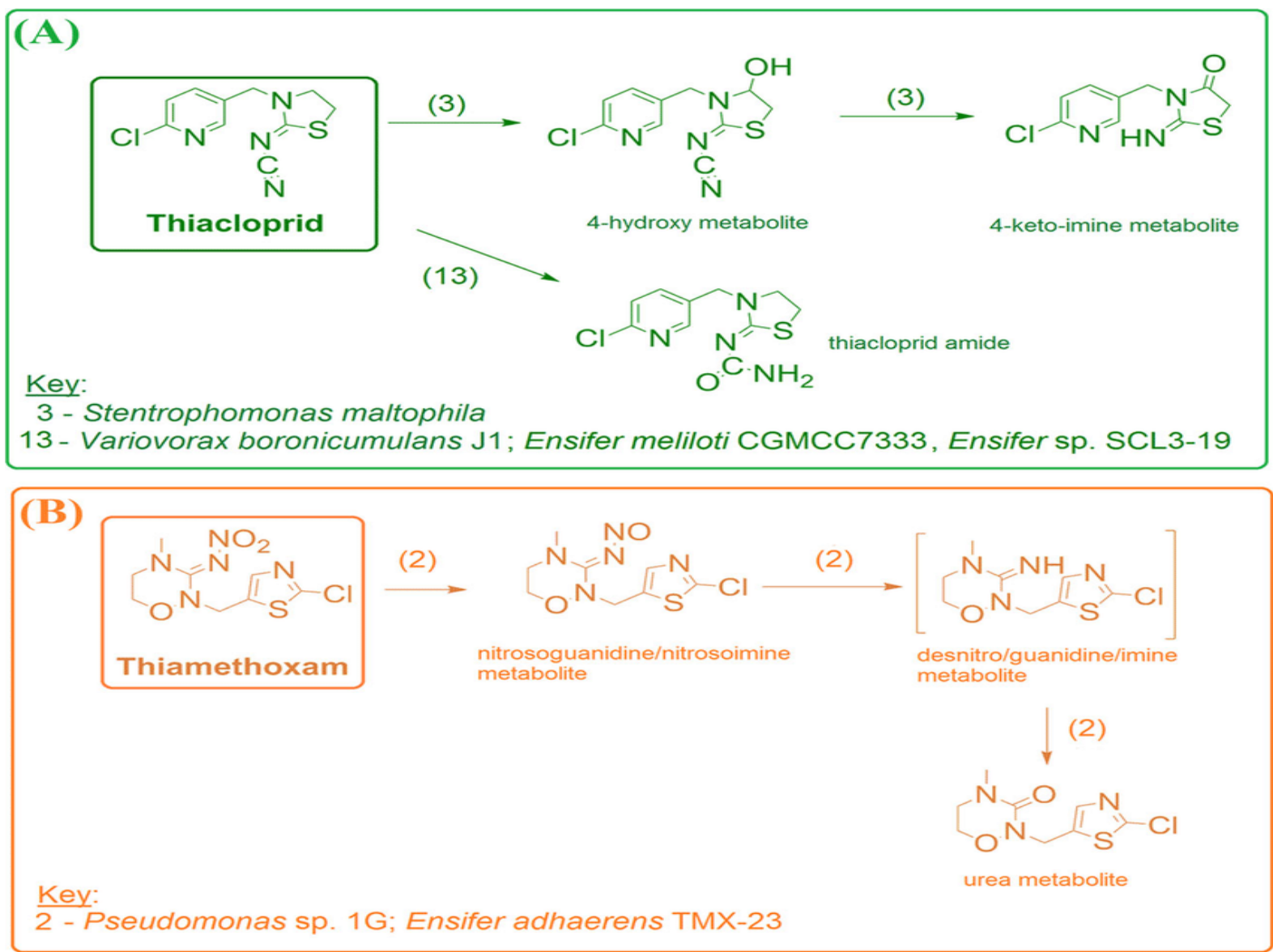
Acetamiprid-degrading bacteria Pseudomonas sp. strain $\mathrm{FH} 2$ could grow optimally at $\mathrm{pH} 7.0$ and $30^{\circ} \mathrm{C}$ temperature in mineral medium with $800 \mathrm{mg} / \mathrm{L}$ concentration and about 53.3 per cent acetamiprid was degraded after incubation for $14 \mathrm{~d}$, while nearly 96.7 per cent was degraded when incubated in acetamipridyeast mineral medium at $30^{\circ} \mathrm{C}$ for $14 \mathrm{~d}$ (Yao and Min, 2006). This paper describes phylogenetic and degradation characterization of a pure bacterium being able to mineralize acetamiprid for the first time. The effect of different temperatures $(20,25,30,35$ and 40 $\left.{ }^{\circ} \mathrm{C}\right)$ and $\mathrm{pH}(5,6,7,8$ and 9) was tested on imidacloprid biodegradation rate and it was noticed that the optimum conditions for biodegradation were a $\mathrm{pH}$ of 8 and $30^{\circ} \mathrm{C}$ temperature ( $\mathrm{Hu}$ et al., 2013). Sharma et al., (2014) have reported that Enterobacter sp. strain ATA1 was a competent bacterium for imidacloprid degradation at $\mathrm{pH}$ between 6.0 and 7.0 and $37^{\circ} \mathrm{C}$ temperature. optimum imidacloprid degradation efficiency of four isolates was achieved at $25^{\circ} \mathrm{C}$ temperature and at neutral $\mathrm{pH} 7.0$ after carrying out the study at three temperatures $\left(65,25\right.$ and $\left.5{ }^{\circ} \mathrm{C}\right)$ and three $\mathrm{pH}$ (4, 7 and 10) (Shaikh et al., 2014). Maximum rate of biodegradation of imidacloprid and acetamiprid by Klebsiella pneumonia and Rhodococcus sp., respectively, occurred at neutral $\mathrm{pH}(7.0)$ and temperature ranging between 30 to $35^{\circ} \mathrm{C}$ after considering the effect of various physicochemical parameters like temperature, $\mathrm{pH}$, initial concentration of insecticides and application of additional nutrient sources (Phugare et al., 2013; Phugare and Jadhav, 2015). However, imidacloprid degradation was slightly better under alkaline conditions than acidic conditions. Acetamiprid degradation could be maximized at a temperature of $35^{\circ} \mathrm{C}$ under mesophilic conditions suitable for degrading bacteria. They concluded further that lower degradation rate under acidic and alkaline conditions than under neutral conditions might be due to the suppressed bacterial growth under these conditions. Microbial growth and enzymatic activity might be the reason for the effect of temperature on biodegradation rate. Substrate toxicity could slow down the biotransformation rate due to increased initial concentration of insecticides as reported by them. They observed that imidacloprid degradation was 78.3 per cent with an initial concentration of $50 \mathrm{mg} / \mathrm{L}$ which significantly reduced to 9 per cent with an initial concentration of $250 \mathrm{mg} / \mathrm{L}$. Similarly, 85 per cent biodegradation rate was achieved with $50 \mathrm{mg} / \mathrm{L}$ of acetamiprid, but only 14 per cent biodegradation rate was recorded with $250 \mathrm{mg} / \mathrm{L}$ of acetamiprid. The application of additional nutrient sources also significantly affected the rate of biodegradation of acetamiprid. Yeast extract as a carbon and nitrogen source accelerated the degradation rate, while citric acid retarded it. Likewise, acetamiprid degradation rate was repressed with the application of sodium nitrate as a nitrogen source. Yang et al., (2013) have isolated Pigmentiphaga sp. D-2 capable of degrading acetamiprid in a liquid medium from $0.22 \mathrm{mM}$ to a non-detectable level within $72 \mathrm{~h}$ at a wide temperature range of 30 to $45^{\circ} \mathrm{C}$ under $\mathrm{pH}$ range of 5 to 10 . Bacterial species Bacillus aeromonas strain IMBL 4.1 and Pseudomonas putida strain IMBL 5.2 could grow optimally at $37{ }^{\circ} \mathrm{C}$ under shake culture conditions in MSMT medium at $\mathrm{pH}$ of $6.0-6.5$ where improved thiamethoxam degradation by these bacterial species was noticed (Rana et al., 2015). These species caused maximum thiamethoxam degradation only in the presence of thiamethoxam as sole source of carbon and energy. In our laboratory it was observed that Pseudomonas mosselii strain NG1, an imidacloprid degrading bacteria isolated form mango orchard soil, could show optimum degradation potential at $35^{\circ} \mathrm{C}$ temperature and neutral pH 7.0 (Bhattacherjee et al., 2018). These studies clearly suggest that for 
successful bioremediation of neonicotinoid insecticides establishment of optimum biotic and abiotic environmental conditions is extremely desirable.

\section{Looking ahead}

The metabolic fate of imidacloprid is still not clear from the researches mentioned above which leaves a gap to understand biotransformation of neonicotinoid insecticides. Better biodegradation of imidacloprid can be achieved when its metabolic fate by all the reported and similar bacteria will be crystal clear. Till date not a single study is available on complete mineralization of imidacloprid by a single bacteria isolate. Therefore, isolating or devising such a bacterium or a bacterial consortium may be crucial for successful biodegradation of not only imidacloprid but other neonicotinoid insecticides also in the soil environment. A clear observation on neonicotinoid biodegradation pathway in soil isolated bacteria / other microbes is somehow missing today though metabolism of these insecticides in several other biological systems has been extensively studied. The identified common mechanism for the biotransformation of chloropyridinylmethyl neonicotinoid insecticides in some biological systems is spontaneous conversion of an unnamed intermediate to 6-CNA via $\mathrm{N}$ methylene hydroxylation (Casida, 2011). Though complete mineralization of imidacloprid by a single bacterium is yet to be studied, 6-CNA has been reported as deadend product of both imidacloprid and acetamiprid metabolism for many bacteria (Figure 1). It can be suggested from these reports that complete mineralization pathway for chloropyridinylmethyl neonicotinoids by microorganisms might proceed via 6-CNA. N-Methylene hydroxylation (yet to be reported in bacteria) or the sequential catabolism of the cyclic N-nitroimine moiety in imidacloprid, the $\mathrm{N}$-cyanoimine moiety in thiacloprid, the acyclic N-cyanoimine moiety in acetamiprid or the 2-nitromethylene moiety in nitenpyram might be the possible reason for the formation of 6-CNA as a metabolic intermediate due to bacterial degradation of chloropyridinylmethyl neonicotinoid insecticides. Some researchers have identified a chemolithoautotropic bacterium from Bradyrhizobiaceae family, strain SG-6C, capable of mineralizing 6-CNA (Pearce et al., 2011; Shettigar et al., 2012). This strain (SG6C) possessed a novel gene encoding a 6CNA dechlorinating hydrolase enzyme through an integrative and conjugative element, a 139-kb mobile element capable of conjugative transfer and integration into the genome at a particular 48-bp recognition sequence. This hydrolase enzyme feeds 6CNA into a pre-existing/possible nicotinic acid mineralization pathway in strain SG-6C.

This study is the only research available till date regarding the evolution of neonicotinoid catabolism in bacterial gene despite the fact that the introduction of neonicotinoid insecticides can provide an alluring model system to examine the catabolic pathway evolution for xenobiotic pesticides in bacteria. The expansion of this research area might not only enlighten the microbial biotransformation of neonicotinoid insecticides but also significantly enhance the progress towards the research on genetic engineering of a neonicotinoid-mineralizing microorganism especially bacterium.

\section{Acknowledgement}

The authors are grateful to the Council of Science \& Technology, Uttar Pradesh, Lucknow, India for providing financial support of the present study in the form of a project grant vide Council's Letter No. CST/AAS/D-1542 dated 02/08/2017. 


\section{References}

Akoijam, R. and Singh, B. 2015. Biodegradation of imidacloprid in sandy loam soil by Bacillus aerophilus. International Journal of Environmental Analytical Chemistry. 95:730-743.

Alexander, $\quad$ A.C., Culp, J.M., Liber, K. and Cessna, A.J. 2007. Effects of insecticide exposure on feeding inhibition in mayflies and oligochaetes. Environmental Toxicology and Chemistry. 26:1726-1732.

Anhalt, J.C., Moorman, T.B. and Koskinen, W.C. 2007. Biodegradation of imidacloprid by an isolated soil microorganism. Journal of Environmental Science and Health, Part B. 42:509-514.

Bhattacherjee, A.K., Garg, N., Shukla, P.K., Singh, B., Vaish S. and Dikshit A. 2018. Microbial degradation of imidacloprid in mango orchard soil. Paper presented in International Conference on Sustainable Organic Agri-Horti Systems, November 2830, 2018, Lucknow, pp. 82-83.

Bhattacherjee, A.K., Shukla, P.K. and Dikshit, A. 2019. Dissipation of imidacloprid residues in mango orchard soil quantified by HPLC. Journal of Eco-Friendly Agriculture. 14(2):50-53.

Bonmatin, J.M., Giorio, C., Girolami, V., Goulson, D., Kreutzweiser, D.P., Krupke, C., Liess, M., Long, E., Marzaro, M., Mitchell, E.A.D., Noome, D.A., SimonDelso, N. and Tapparo, A. 2015. Environmental fate and exposure; neonicotinoids and fipronil. Environmental Science and Pollution Research. 22:35-67. https://doi.org/10.1007/s11356-014-3332-7.

Casida, J. 2011. Curious about pesticide action. Journal of Agricultural and Food Chemistry. 59:2762-2769.

Chen, T., Dai, Y.J., Ding, J.F., Yuan, S. and Ni, J.P. 2008. N-demethylation of neonicotinoid insecticide acetamiprid by bacterium Stenotrophomonas maltophilia CGMCC 1.1788. Biodegradation. 19:651-658.

Cox, L., Koskinen, W.C. and Yen, P.Y. 1997. Sorption-desorption of imidacloprid and its metabolites in soil. Journal of Agricultural and Food Chemistry. 45:1468-1472.

Cox, L., Koskinen, W. and Yen,
P. 1998. Influence of soil properties on sorption - desorption of imidacloprid. Journal of Environmental Science and Health, Part B. 33:123-134.

Cresswell, J.E. 2011. A meta-analysis of experiments testing the effects of a neonicotinoid insecticide (imidacloprid) on honey bees. Ecotoxicology. 20:149-157.

Dai, Y.J., Ji, W.W., Chen, T., Zhang, W.J., Liu, Z.H., Ge, F. and Yuan, S. 2010. Metabolism of the neonicotinoid insecticides acetamiprid and thiacloprid by the yeast Rhodotorula mucilaginosa strain IM-2. Journal of Agricultural and Food Chemistry. 58:2419-2425.

Elbert, A., Nauen, R. and Leicht, W. 1998. Imidacloprid, a novel chloronicotinyl insecticide: biological activity and agricultural importance. In: Ishaaya I and Degheele D (eds.) Insecticides with Novel Modes of Action. Applied Agriculture. Springer, Berlin, Heidelberg. Pages 50-73.

Elbert, A., Haas, M., Springer, B., Thielert, W. and Nauen, R. 2008. Applied aspects of neonicotinoid uses in crop protection. Pest Management Science 64:1099-1105.

Ganvir, V.N. and Sathe, S.J. 2018. Isolation and characterization of imidacloprid degrading microorganisms from pesticide contaminated soil. International Journal of Pharmacy and Biological Sciences. 8:108112.

Garg, N., Bhattacherjee, A.K. and Jyotsna. 2018. Bacterial degradation of imidacloprid and carbosulfan under in vitro condition in mango (Mangifera indica) - a preliminary study. Current Horticulture 6(2):23-26.

Ge, F., Zhou, L.Y., Wang, Y., Ma, Y., Zhai, S., Liu, Z.H., Dai, Y.J. and Yuan, S. 2014. Hydrolysis of the neonicotinoid insecticide thiacloprid by the $\mathrm{N}_{2}$-fixing bacterium Ensifer meliloti CGMCC 7333. International Biodeterioration and Biodegradation. 93:1017.

Gopal, M., Dutta, D., Jha, S.K., Kalra, S., Bandyopadhyay, S. and Das, S.K. 2011. Biodegradation of imidacloprid and metribuzin by Burkholderia cepacia strain $\mathrm{CH}$ 9. Pesticide Research Journal. 23(1):3640.

Goulson, D. 2013. Review: an overview of the 
environmental risks posed by neonicotinoid insecticides. Journal of Applied Ecology. 50:977-987.

Gupta, S., Gajbhiye, V.T. and Gupta, R.K. 2008. Soil dissipation and leaching behavior of a neonicotinoid insecticide thiamethoxam. Bulletin of Environmental Contamination and Toxicology. 80:431-437.

Han, P., Niu, C.Y., Lei, C.L., Cui, J.J. \& Desneux, N. 2010. Quantification of toxins in a Cry1Ac+CpTI cotton cultivar and its potential effects on the honey bee Apis mellifera L. Ecotoxicology. 19:1612-1619.

Henry, M., Beguin, M., Requier, F., Rollin, O., Odoux, J.F., Aupinel, P., Aptel, J., Tchamitchian, S. and Decourtye, A. 2012. A common pesticide decreases foraging success and survival in honeybees. Science. 336:350-351.

Hu, G., Zhao, Y., Liu, B., Song, F. and You, M. 2013. Isolation of an indigenous imidacloprid-degrading bacterium and imidacloprid bioremediation under simulated in situ and ex situ condition. Journal of Microbiology and Biotechnology. 23(11):1617-1626. http://dx.doi.org/10.4014/jmb.1305.05048.

Hussain, S., Hartley, C.J., Shettigar, M. and Pandey, G. 2016. Bacterial biodegradation of neonicotinoid pesticides in soil and water systems. FEMS Microbiology Letters. 363(23):fnw252.

Jeschke, P., Nauen, R., Schindler, M. and Elbert, A. 2011. Overview of the status and global strategy for neonicotinoids. Journal of Agricultural and Food Chemistry. 59:28972908.

Kandil, M.M., Trigo, C., Koskinen, W.C. and Sadowsky, M.J. 2015. Isolation and characterization of a novel imidaclopriddegrading Mycobacterium sp. strain MK6 from an Egyptian soil. Journal of Agricultural and Food Chemistry. 63:47214727. DOI:10.1021/acs.jafc.5b00754.

Kreutzweiser, D.P., Good, K.P., Chartrand, D.T., Scarr, T.A., Holmes, S.B. and Thompson, D.G. 2008. Effects on litter dwelling earthworms and microbial decomposition of soil-applied imidacloprid for control of wood-boring insects. Pest Management Science. 64:112-118.
Krischik, V.A., Landmark, A. and Heimpel, G. 2007. Soil-applied imidacloprid is translocated to nectar and kills nectarfeeding Anagyrus pseudococci (Girault) (Hymenoptera: Encyrtidae). Environmental Entomology. 36:1238-1245.

Krupke, C.H., Hunt, G.J., Eitzer, B.D., Andino, G. and Given, K. 2012. Multiple routes of pesticide exposure for honey bees living near agricultural fields. PLoS One. 7:e29268.

Liu, Z., Dai, Y., Huang, G., Gu, Y., Ni, J., Wei, H. and Yuan, S. 2011. Soil microbial degradation of neonicotinoid insecticides imidacloprid, acetamiprid, thiacloprid and imidaclothiz and its effect on the persistence of bioefficacy against horsebean aphid Aphis craccivora Koch after soil application. Pest Management Science. 67:1245-1252. https://doi.org/10.1002/ps.2174.

Liu, Z., Yan, X., Xu, X. and Wang, M. 2013. Development of a chemiluminescence enzyme-linked immunosorbent assay for the simultaneous detection of imidaclothiz and thiacloprid in agricultural samples. Analyst. 138:3280-3286. DOI: $10.1039 /$ C3AN00205E.

Liu,W.P., Zheng, W., Ma, Y., Liu, K.K. 2006. Sorption and degradation of imidacloprid in soil and water. Journal of Environmental Science and Health Part B. 41:623-634.

Ma, Y., Zhai, S., Mao, S.Y., Sun, S.L., Wang, Y., Liu, Z.H., Dai, Y.J. and Yuan, S. 2014. Cometabolic transformation of the neonicotinoid insecticide imidacloprid by the new soil isolate Pseudoxanthomonas indica CGMCC 6648. Journal of Environmental Science and Health, Part B. 49:661-670.

Marzaro, M., Vivan, L., Targa, A., Mazzon, L., Mori, N., Greatti, M., Toffolo, E.P., Bernardo, A.D., Giorio, C., Marton, D., Tapparo, A. and Girolami, V. 2011. Lethal aerial powdering of honey bees with neonicotinoids from fragments of maize seed coat. Bulletin of Insectology. 64:119126.

Moghaddam, N.S., Zakaria, M.P., Omar, D., Sijam, K. and Khakvar, R. 2011. Effects of imidacloprid on the biodiversity of soil microbes in selected soils of Malaysia. In: 
$2^{\text {nd }}$ International Conference on Environmental Science and Development, IPCBEE. 4:7-10.

Mommaerts, V., Reynders, S., Boulet, J., Besard, L., Sterk, G. and Smagghe, G. 2010. Risk assessment for side- effects of neonicotinoids against bumblebees with and without impairing foraging behaviour. Ecotoxicology. 19:207-215.

Myresiotis, C.K., Vryzas, Z. and PapadopoulouMourkidou, E. 2012. Biodegradation of soilapplied pesticides by selected strains of plant growth-promoting rhizobacteria (PGPR) and their effects on bacterial growth. Biodegradation. 23:297-310. https://doi.org/10.1007/s10532-011-9509-6.

Nauen, R., Reckmann, U., Armborst, S., Stupp, H.P. and Albert, A. 1999. Whitefly-active metabolites of imidacloprid: biological efficacy and translocation in cotton plants. Pesticide Science. 55:265-71. https://doi.org/10.1002/(SICI)1096-

9063(199903)55:3<265::AIDPS891>3.0.CO;2-C.

Negi, G., Srivastava, A. and Sharma A. 2014. In situ biodegradation of endosulfan, imidacloprid and carbendazim using indigenous bacterial cultures of agriculture fields of Uttarakhand, India. International Journal of Bioengineering and Life Sciences. 8(9):973-981.

Pandey, G., Dorrian, S.J., Russell, R.J. and Oakeshott, J.G. 2009. Biotransformation of the neonicotinoid insecticides imidacloprid and thiamethoxam by Pseudomonas sp. 1G. Biochemical and Biophysical Research Communication. 380:710-714. https://doi: 10.1016/j.bbrc.2009.01.156.

Pearce, S.L., Pandey, R., Dorrian, S.J., Russell, R.J., Oakeshott, J.G. and Pandey, G. 2011. Genome sequence of the newly isolated chemolithoautotrophic Bradyrhizobiaceae strain SG-6C. Journal of Bacteriology. 193(18):5057.

Phugare, S.S. and Jadhav, J.P. 2015. Biodegradation of acetamiprid by isolated bacterial strain Rhodococcus sp. $\mathrm{BCH} 2$ and toxicological analysis of its metabolites in silkworm (Bombyx mori). CLEAN-Soil Air Water. 43(2):296-304. DOI: 10.1002/clen.201200563.
Phugare, S.S., Kalyani, D.C., Gaikwad, Y.B. and Jadhav, J.P. 2013. Microbial degradation of imidacloprid and toxicological analysis of its biodegradation metabolites in silkworm (Bombyx mori). Chemical Engineering Journal. 230:27-35.

Plumb, D.C. 2015. Veterinary Drug Handbook. 8th ed. (pocket). Ames, IA: WileyBlackwell. Pages 1048.

Rana, S. and Gupta, V.K. 2019. Microbial degradation of second generation neonicotinoid: thiamethoxam in clay loam soils. Journal of Pharmacognosy and Phytochemistry. SP1:294-298.

Rana, S., Jindal, V., Mandal, K., Kaur, G. and Gupta, V.K. 2015. Thiamethoxam degradation by Pseudomonas and Bacillus strains isolated from agricultural soils. Environmental Monitoring and Assessment. 187:300. DOI 10.1007/s10661-015-4532-4.

Rouchaud, J., Gustin, F. and Wauters, A. 1994. Soil biodegradation and leaf transfer of insecticide imidacloprid applied in seed dressing in sugar beet crops. Bulletin of Environmental Contamination and Toxicology. 53:344-350.

Sabourmoghaddam, N., Zakaria, M.P. and Omar, D. 2014. Evidence for the microbial degradation of imidacloprid in soils of Cameron Highlands. Journal of the Saudi Society of Agricultural Sciences, King Saud University. $\quad$ DOI: 10.1016/j.jssas.2014.03.002.

Sarkar, M.A., Roy, S., Kole, R.K. and Chowdhury, A. 2001. Persistence and metabolism of imidacloprid in different soils of West Bengal. Pest Management Science. 57:598-602.

Schuld, M. and Schmuck, R. 2000. Effects of thiacloprid, a new chloronicotinyl insecticide, on the egg parasitoid Trichogramma cacaoeciae. Ecotoxicology. 9:197-205. doi:10.1023/A:1008994705074.

Shaikh, N.S., Kulkarni, S.V., Mulani, M.S. and Baig, U.I. 2014. Biodegradation of imidacloprid, the new generation neurotoxic insecticide. International Journal of Innovative Science, Engineering and Technology. 3:16301-16307.

Sharma, S., Singh, B. and Gupta, V.K. 2014. Biodegradation of imidacloprid by 
consortium of two soil isolated Bacillus sp. Bulletin of Environmental Contamination and Toxicology. 93:637-642.

Sharma, S., Singh, B. and Gupta, V.K. 2016. Bacillus aerophilus mediated degradation of imidacloprid in soil. Pesticide Research Journal. 28(1):95-103.

Sharma, T., Rajor, A. and Toor, A.P. 2014. Degradation of imidacloprid in liquid by Enterobacter sp. strain ATA1 using cometabolism. Bioremediation Journal. 18(3):227-235.

https://doi.org/10.1080/10889868.2014.9185 75.

Shetti, A.A. and Kaliwal, B.B. 2012. Biodegradation of imidacloprid by soil isolate Brevunimonas sp. MJ15. International Journal of Current Research. 4:100-106.

Shetti, A.A., Kaliwal, R.B. and Kaliwal, B.B. 2014. Imidacloprid induced intoxication and its biodegradation by soil isolate Bacillus weihenstephanensis. British Biotechnology Journal. 4:957-969.

Shettigar, M., Pearce, S.L., Pandey, R., Khan, F.R., Dorrian, S.J., Balotra, S., Russell, R.J., Oakeshott, J.G. and Pandey, G. 2012. Cloning of a novel 6-chloronicotinic acid chlorohydrolase from the newly isolated 6chloronicotinic acid mineralizing Bradyrhizobiaceae strain SG-6C. PLoS One. 7(11):e51162.

doi: 10.1371/journal.pone.0051162.

Shi, Z., Dong, W., Xin, F., Liu, J., Zhou, X., Xu, F., Lv, Z., Ma, J., Zhang, W., Fang, Y. and Jiang, M. 2018. Characteristics and metabolic pathway of acetamiprid biodegradation by Fusarium sp. strain CS-3 isolated from soil. Biodegradation. 29(6):593-603. doi: 10.1007/s10532-0189855-8.

Suchail, S., Sousa, G.D., Rahmani, R. and Belzunces, L.P. 2004. In vivo distribution and metabolisation of 14C-imidacloprid in different compartments of Apis mellifera L. Pest Management Science. 60:1056-1062. DOI: $10.1002 / p s .895$.

Sur, R. and Stork, A. 2003. Uptake, translocation and metabolism of imidacloprid in plants. Bulletin of Insectology. 56:35-40.

Tang, H.Z., Li, J., Hu, H.Y. and Xu, P. 2012. A newly isolated strain of Stenotrophomonas sp. hydrolyzes acetamiprid, a synthetic insecticide. Process Biochemistry. 47:18201825. http://dx.doi.org/10.1016/j.procbio.2012.06. 008.

Tapparo, A., Marton, D., Giorio, C., Zanella, A., Solda, L., Marzaro, M., Vivan, L. and Girolami, V. 2012. Assessment of the environmental exposure of honeybees to particulate matter containing neonicotinoid insecticides coming from corn coated seeds. Environmental Science \& Technology. 46(5):2592-2599.

United States Environmental Protection Agency. 2004. Dinotefuran Pesticide Fact Sheet. Pages 63. Accessed on 22/01/2020, https://en.wikipedia.org/wiki/Dinotefuran.

van der Sluijs, J.P., Amaral-Rogers, V., Belzunces, L.P., Lexmond, M.F.I.J.B., Bonmatin, J.M., et al., 2014. Conclusions of the worldwide integrated assessment on the risks of neonicotinoids and fipronil to biodiversity and ecosystem functioning. Environmental Science and Pollution Research. 22: 148-154. DOI: 10.1007/s11356-014-3229-5.

Vineyard, C.J. and Stewart, S. 2017. Microbial degradation of neonicotinoid insecticides in the soil and potential implication on thrips (Thysanoptera: Thripidae) control in cotton. The Journal of Cotton Science. 21:128-133.

Wang, G., Chen, X., Yue, W., Zhang, H., Li, F. and Xiong, M. 2013a. Microbial degradation of acetamiprid by Ochrobactrum sp. D-12 isolated from contaminated soil. PLoS One. 8(12):e82603.

Wang, G., Yue, W., Liu, Y., Li, F., Xiong, M. and Zhang, H. 2013b. Biodegradation of the neonicotinoid insecticide acetamiprid by bacterium Pigmentiphaga sp. strain AAP-1 isolated from soil. Bioresource Technology. 138:359-368. https://doi.org/10.1016/j.biortech.2013.03.19 3.

Wang, G.L., Zhao, Y.J., Gao, H., Yue, W., Xiong, M., Li, F., Zhang, H. and Ge, W. 2013c. Cometabolic biodegradation of acetamiprid by Pseudoxanthomonas sp. AAP-7 isolated from a long-term acetamiprid-polluted soil. Bioresource Technology. 150:259-265. 
http://dx.doi.org/10.1016/j.biortech.2013.10. 008.

Wang, G., Zhu, D., Xiong, M., Zhang, H. and Liu, Y. 2016. Construction and analysis of an intergeneric fusion from Pigmentiphaga sp. strain AAP-1 and Pseudomonas sp. CTN-4 for degrading acetamiprid and chlorothalonil. Environmental Science and Pollution Research. 23:13235-13244. https://doi.org/10.1007/s11356-016-6482-y.

Yang, E.C., Chuang, Y.C., Chen, Y.L. and Chang, L.H. 2008. Abnormal foraging behavior induced by sublethal dosage of imidacloprid in the honey bee (Hymenoptera: Apidae). Journal of Economic Entomology. 101:1743-1748.

DOI: 10.1603/0022-0493-101.6.1743.

Yang, H., Wang, X., Zheng, J., Wang, G., Hong, Q., Li, S., Li, R. and Jiang, J. 2013. Biodegradation of acetamiprid by Pigmentiphaga sp. D-2 and the degradation pathway. International Biodeterioration and Biodegradation. 85:95-102.

Yao, X.H. and Min, H. 2006. Isolation characterization and phylogenetic analysis of a bacterial strain capable of degrading acetamiprid. Journal of Environmental Science (China). 18(1):141-146.

Yao, X.H., Min, H., Lü, Z.H. and Yuan, H.P. 2006. Influence of acetamiprid on soil enzymatic activities and respiration. European Journal of Soil Biology. 42(2):120-126.

doi:10.1016/j.ejsobi.2005.12.001.

Zhang, H.J., Zhou, Q.W., Zhou, G.C., Cao, Y.M., Dai, Y.J., Ji, W.W., Shang, G.D. and Yuan, S. 2012. Biotransformation of the neonicotinoid insecticide thiacloprid by the bacterium Variovorax boronicumulans strain $\mathrm{J} 1$ and mediation of the major metabolic pathway by nitrile hydratase. Journal of Agricultural and Food Chemistry. 60:153159. https://doi.org/10.1021/jf203232u.

Zhao, Y.J., Dai, Y.J., Yu, C.G., Luo, J., Xu, W.P., Ni, J.P. and Yuan, S. 2009. Hydroxylation of thiacloprid by bacterium Stenotrophomonas maltophilia CGMCC1.1788. Biodegradation. 20:761-768. https://doi.org/10.1007/s10532-009-9264-0.

Zhou, G.C., Wang, Y., Zhai, S., Ge, F., Zhong, H.L., Dai, Y.J., Yuan, S. and Hou, J.Y. 2013. Biodegradation of the neonicotinoid insecticide thiamethoxam by the nitrogen fixing and plant-growth-promoting rhizobacterium Ensifer adhaerens strain TMX-23. Applied Microbiology and Biotechnology. 97:4065-4074. DOI 10.1007/s00253-012-4638-3.

Zhou, G.C., Wang, Y., Zhai, S., Zhou, L.Y., Dai, Y.J. and Yuan, S. 2014a. The metabolism of neonicotinoid insecticide thiomethoxam by soil enrichment cultures, and the bacterial diversity and plant-growth-promoting properties of the cultured isolates. Journal of Environmental Science and Health Part B. 49:381-390.

DOI: 10.1080/03601234.2014.894761.

Zhou, G.C., Zhang, Y., Sun, S.L., Ge, F., Mao, S.Y., Ma, Y., Liu, Z.H., Dai, Y.J. and Yuan, S. 2014b. Degradation of the neonicotinoid insecticide acetamiprid via the $N$ carbamoylimine derivative (IM-1-2) mediated by the nitrile hydratase of the nitrogen-fixing bacteria Ensifer meliloti CGMCC7333. Journal of Agricultural and Food Chemistry. 62 (41):9957-9964. https://doi.org/10.1021/jf503557t.

\section{How to cite this article:}

Anup K. Bhattacherjee, Pradeep K. Shukla and Abhay Dikshit. 2020. Microbial Biotransformation of Neonicotinoid Insecticides in Soil - A Review. Int.J.Curr.Microbiol.App.Sci. 9(07): 3255-3277. doi: https://doi.org/10.20546/ijcmas.2020.907.380 